\title{
The Political Contingency of Public Opinion, or What Shall We Make of the Declining Faith of Middle-Class African Americans?
}

\section{Citation}

Hochschild, Jennifer. 1994. The political contingency of public opinion, or what shall we make of the declining faith of middle-class African Americans? PS: Political Science and Politics 27, no. 1: 35-38.

\section{Published Version}

http://dx.doi.org/10.2307/420455

\section{Permanent link}

http://nrs.harvard.edu/urn-3:HUL.InstRepos:3347580

\section{Terms of Use}

This article was downloaded from Harvard University's DASH repository, and is made available under the terms and conditions applicable to Other Posted Material, as set forth at http:// nrs.harvard.edu/urn-3:HUL.InstRepos:dash.current.terms-of-use\#LAA

\section{Share Your Story}

The Harvard community has made this article openly available.

Please share how this access benefits you. Submit a story.

\section{Accessibility}


for the technical issues of dynamic models of policy as a function of opinion-and particularly those involved in separating linkage through elections from linkage by our direct rational anticipation scenario-prevent more than a cursory look.

We take that cursory look in Figure 5, where we present summary series for Senate, House, and presidency, along with policy mood, our global public opinion measure (lagged one year to keep our causal story straight). They go together. That can be seen by eyeballing and confirmed by simple product moment correlations $(.47, .39$, and .54 for Senate, House, and president). It isn't the last we'll have to say on the issue.

We conclude that our data are consistent with a global view of opinion and policy. General shifts of opinion over time seem connected with general shifts of policy activity. The structure has logic in theory and empirical support. Clearly, however, it does not rule out alternatives. We think it is a plausible story for representation in the long run. But something different was going on, for example, when the new Clinton Administration abandoned nominees in the face of telephone and fax assaults.

What these data begin to suggest is representation of a longitudinal sort, that we can tell a coherent story of citizens altering their basic dispositions toward government, and government then responding. What is satisfying about this global view is both that it works and that it works without heroic assumptions about the level of awareness and involvement of ordinary citizens. It works, that is, with the public opinion we know.

\section{References}

Arnold, R. Douglas. 1990. The Logic of Congressional Action. New Haven: Yale University Press.

Converse, Philip E. 1964. "The Nature of Belief Systems in Mass Publics." In Ideology and Discontent, ed. David E. Apter. New York: Free Press.

Stimson, James A. 1991. Public Opinion in America: Moods, Cycles, and Swings. Boulder, CO: Westview Press.

Stimson, James A., Michael B. MacKuen, Robert S. Erikson, and Paul Kellstedt. 1993. "Dynamic Analysis with Latent Constructs: The Kalman DYMIMIC Specification." Paper presented to the Ninth Annual Meeting of the Political Methodology Society, Tallahassee, FL.

\section{Notes}

*This is a highly abbreviated account of our work in progress, "Dynamic Representation," some modeling aspects of which are reported in Stimson, MacKuen, Erikson, and Kellstedt 1993. This work was supported in part by National Science Foundation Grant, SES-9011807, "Political Eras and Representation." We would like to thank Chris Wlezien, Robert Durr, Tami Buhr, and Paul Kellstedt for notable contributions to the measurement development activities we report here. We are grateful to Jeff Segal for sharing his Solicitor General data with us.

1. This focus on anticipation as the quintessential behavior of elected politicians has much commonality with Arnold's (1990) statement about the congressional part of government.

2. The case may be put negatively as well. Conservatives who once adopted moderation for self-protection would no longer feel the need to do so.

3. The estimates are central tendencies of all available survey marginals for policy preference questions asked in identical format over time. The estimation technology (see Stimson 1991) has a logic akin to that of principal components analysis, and thus the estimates may be thought of as something like factor scores.

\section{About the Authors}

James A. Stimson is Arleen Carlson Professor of Political Science at the University of Minnesota. He is author of Public Opinion in America: Moods, Cycles, and Swings (1991).

Michael B. MacKuen is Professor of Political Science at the University of MissouriSt. Louis.

Robert S. Erikson is Distinguished University Professor of Political Science at the University of Houston.

\title{
The Political Contingency of Public Opinion, or What Shall We Make of the Declining Faith of Middle-Class African Americans?
}

\author{
Jennifer Hochschild, Princeton University
}

S cholars who study the connections between public opinion and the policy process, and politicians who engage in making those connections, face the same two problems. First, determining what opinion the public actually holds is much more of an interpretive than a methodological exercise. Second, designing policies to respond to that (presumed) opinion is at best an inexact art and at worst a demonstration that making the wrong moves can produce more harm than good. This essay illustrates these points by examining race politics in America over the past three decades.

In order to move quickly to those illustrations, let me stipulate, with minimal evidence, several starting points. First, middle-class African Americans are better off now than middle-class members of their race have ever been; well-off African Americans are getting richer at a faster rate than well-off white Americans (though from a lower absolute starting point); and middle-class African Americans are gaining ground at the same time that poor African Americans are losing it.

Those points require much evidence to be completely persuasive, but they are all illustrated by a simple comparison of income quantiles by race over time (see Table 1 ).

Second, the "American dream" 
TABLE 1

Percent Share of Families' Aggregate Income Held by Wealthy and Poor of Each Race, 1947-1991

\begin{tabular}{|c|c|c|c|c|c|c|c|}
\hline \multicolumn{2}{|l|}{1947} & \multicolumn{2}{|c|}{1967} & \multicolumn{2}{|c|}{1987} & \multicolumn{2}{|c|}{1991} \\
\hline Nonwhite & White & Black & White & Black & White & Black & White \\
\hline $\begin{array}{l}\text { poorest } 40 \% \text { : } \\
\quad 14.7 \\
\text { wealthiest } 40 \%\end{array}$ & 17.7 & 15.0 & 18.3 & 11.9 & 16.3 & 11.6 & 16.0 \\
\hline 69.1 & 65.4 & 68.6 & 64.2 & 72.6 & 66.9 & 72.8 & 67.2 \\
\hline
\end{tabular}

is the dominant political ideology of the United States. The ideology has four related but distinct tenets. They answer the questions: Who may pursue the American dream? In what does the pursuit consist? How does one successfully pursue the dream? Why is the pursuit worthy of our deepest commitment? The answer to "who?" is "everyone, regardless of ascriptive traits, family background, or personal history." The answer to "what?" is "the reasonable anticipation, though not the promise, of success." The answer to "how?"' is "through actions and traits under one's own control." The answer to "why?" is "true success is associated with virtue."

Third, despite their increasing material success, middle-class blacks believe in the American dream less now than their counterparts did 30 years ago. Their sharply declining belief contrasts with poor blacks' much milder decline in belief in the American dream. (Middle-class whites have also lost some faith in the dream, but not nearly as much as middleclass blacks.)

A few examples of survey data must stand in here for a sustained demonstration of this claim. On the first tenet of the American dream, middle-class blacks were more optimistic than poor blacks in the 1960 s, but less so in the 1980s. Asked in 1968 "if a young Negro works hard enough, ... . [can] he or she usually get ahead in this country in spite of prejudice and discrimination?," $7 \%$ more well-educated than poorly educated blacks answered in the affirmative. But asked in 1988 if "blacks have the same opportunities to live a middle class life as whites?," $26 \%$ more poorly educated than well-educated blacks said "yes."'

The same pattern holds for the second tenet. Three decades ago, middle-class blacks were more optimistic than poor blacks. They became less so over time since their belief in the American dream declined so sharply. In 1971, $17 \%$ more high- than low-income African Americans claimed to be "satisfied ... with the future facing you and your family." But 15 years later, $36 \%$ more poor than well-off blacks felt that "looking to the future, ... the American Dream will be easier to attain than today."2

The pattern holds less sharply for the third tenet. Well-off blacks are always less likely than are poor blacks to hold members of their race responsible for their own situation (i.e., well-off blacks are less likely to accept the claim of the ideology), but they were more critical of their fellow blacks in the 1960 s than in the 1980s (i.e., they came closer to accepting the claim of the ideology).

We have too few survey questions on the fourth tenet, about the worthiness of the pursuit, to be confident of any trends over time.

The fourth and final stipulation gives more precision to what middle-class African Americans mean by their declining faith in the American dream. They, like all other groups of Americans, still overwhelmingly endorse our dominant ideology as a prescription for American life. But their faith in the American dream as a description is declining.

For example, virtually all Americans agree that everyone in the United States warrants equal edu- cational opportunities. More pointedly, no more than $10 \%$ of middleclass blacks embrace views posed as alternatives to the American dream such as Afrocentrism, at least in surveys. Furthermore, a strong majority continue to believe, as do well-off whites but not the poor of any race, that their own future looks bright and that they are in control of their lives.

What middle-class blacks are increasingly skeptical about, more than are other groups, is the ability of their children, other members of their race, and sometimes all other citizens of the nation to realize the American dream in their lives. Thus in the eyes of well-off African Americans, the American dream reigns as prescription, rules as description of one's own life, and increasingly falters as a description of others' lives.

Let us, for the sake of argument here, put aside concerns about the dangers of relying on single questions, of comparing questions with different wording over time, and of the poor sampling procedures among African Americans in the 1960s. (It is reassuring that other survey questions show the same pattern, and that qualitative evidence of many kinds supports the claims here. Documentation is in my forthcoming book, Race, Class, and the American Dream.) My concern in this essay is the connections among these opinions, their proper interpretation, and actions taken in the political arena in response to them.

Analysts have two interpretive choices when looking at this set of opinions, and political actors have two behavioral choices. Analytically, we can put the absolute numbers in the foreground and the trajectory in the background, or vice versa. That is, we can focus on the fact that middle-class African Americans still overwhelmingly endorse the American dream and still believe that it describes their own lives, and read the evidence of declining belief as a transient manifestation of opposition to Reaganite conservatism, relative deprivation, or fear of and for the urban underclass. Alternatively, we can focus on the fact that the very segment of 
the population that seems to embody the continuing vitality and efficacy of the American dream is leading the rest of the nation into disillusionment and bitterness. The former interpretation rests on the absolute numbers; the latter interpretation rests on changes in those numbers over time.

Roughly the same two choices are available to political actors. They can assume, as President Clinton did in his campaign and as analysts such as William J. Wilson and Charles Hamilton do, that the significance of race really is declining among the best-off blacks in favor of class-related issues or liberal individualism (Wilson 1980; Hamilton 1993). President Clinton gambled successfully on gaining enough support from black voters (who, like white voters, are disproportionately better off than nonvoters) by focusing on economic issues of job security, health insurance, and deficit reduction rather than by invoking civil rights history or demands for racial equity.

Professor Hamilton even argues that the 1992 presidential election signaled the demise of the racially structured presidential campaigns of the last 30 years. Organizing politics around race is no longer, he claims, in the interests of the Republican Party (chastened by Willie Horton and David Duke), the Democratic Party (able to win without it), or black elites (sufficiently secure to move beyond racially based politics to their other perennial concern for social welfare issues). Political actors may, in short, judge that middle-class African Americans' overall continued endorsement of the American dream and their confidence in their own ability to succeed according to its precepts is the real story, and their growing skepticism is either temporary or narrowly focused on bounded concerns.

Political actors may, however, interpret public opinion differently. They may agree with Lani Guinier, Louis Farrakhan, and Ben Chavis that race still determines what happens even to well-off African Americans more than do class or individual characteristics, and that time is running out on blacks' patience with discrimination and stigmatization. A shared focus on race does not lead to shared policy goals or political strategies, as a quick canvass of the views of these three actors shows. But these actors are united in their claim that middleclass blacks are still more black than middle class, and in their insistence that racially targeted policies are essential if blacks are ever to get, and to believe that they are getting, fair rewards for their efforts. Put more schematically, political actors may judge that absent drastic action, middle-class African Americans' growing skepticism about the American dream will

... political actors may judge that absent drastic action, middle-class African Americans, growing skepticism about the American dream will eventually overwhelm their historical faith in democracy and opportunity, if it has not already done so.

eventually overwhelm their historical faith in democracy and opportunity, if it has not already done so.

Of course, neither political actors nor analysts operate in a vacuum. The choices of the former are constrained by all of the things implied by the phrases "socioeconomic context" and "political structure"ranging from multinational corporations' choices about where to locate factories to the arithmetic of single-member legislative districts. The judgments of the latter are constrained by the quality and range of the data they rely on and by the assumptions and commitments they bring to the interpretation of those data. Nevertheless, the great complexity and fluidity of middle-class African Americans' beliefs about the American dream allow politicians and analysts as wide an interpretative screen and as much freedom of movement as any person can cope with.

How will well-off African Americans respond, in turn, to politicians' actions and analysts' interpretations? (Anticipation of their responses is, of course, one of the constraints faced by politicians and analysts.) I see two possible directions, corresponding to the two sets of interpretative judgments and political choices described above.

Middle-class blacks may by now be sufficiently integrated, behaviorally if not psychologically and culturally, into mainstream (i.e., white-dominated) society that their faith in the American dream will over the long run be reinforced. After all, middle-class African Americans by definition (that is, as I have defined them in my reanalyses of the survey data) are well educated and have high incomes. Most also have white collar jobs, live in comfortable if not racially mixed neighborhoods, and face no direct legal or behavioral barriers to further success. They still mostly vote for Democrats, but surveys show that they are becoming more conservative on economic and social welfare policies compared with poorer African Americans or with middle-class African Americans 20 years ago. They have ample grounds therefore, to put it schematically, to trust their longstanding faith in the prescriptions of the American dream and to interpret their own success in its terms, and eventually to halt or reverse their current disillusionment about its efficacy for other blacks and nonblack Americans. (Their disillusionment could halt or reverse for either of two reasonsmiddle-class African Americans could worry less about poor blacks, thus coming to resemble well-off whites' views on poor whites, or they could regain faith that other African Americans will be able to succeed as they themselves have done.)

However, well-off African Americans' disillusionment may grow to 
the point that it affects their general faith in the American dream and their confidence about their own future. If middle-class blacks feel betrayed by President Clinton's abandonment of Lani Guinier, if they fear that continued recession threatens their own hard-won economic and social standing, if they despair for the desperately poor African Americans trapped in nihilistically violent ghettos, if they fear that their children will suffer the consequences of the end of the "second Reconstruction," if they cannot conquer or ignore persistent subtle racism in their work and neighborhoods-then the recent changes in their beliefs will affect even those aspects of their belief that have not yet crumbled. At worst, most African Americans will come to feel what some now believe, that to succeed on the terms set by the dominant ideology is to go over to the enemy and to betray one's own.

Sensitive political actors understand this danger. Senator Bradley's challenge to then-President Bush and Professor Guinier's insistence that her goal is racial integration and understanding stand out as evidence that politicians are able to recognize that these issues are too serious for the politics of electoral safety or personal vengeance. Public policies may even be able to tip the balance of middle-class African Americans' allegiances toward the American dream if political actors can figure out how to respond simultaneously to racial and classbased anxieties.

Thus in this case the interactions among opinion, interpretation, and political action are not only more complicated than we usually real- ize-that may be true of any interaction worth attending to-but also more fraught. Most media and public attention, for good reason, is devoted to the small fraction of poor young men in large cities who have lost faith in any personal morality or social constraints. But at least some attention should be devoted to the more subtle but potentially just as serious loss of faith among those who seem to exemplify the American dream. It is one thing for jobless, illiterate, destitute young men to lash out at the society that apparently finds them expendable; it is quite another for professional, well-educated, wellpaid men and women to become embittered at the society that apparently searches for them eagerly. Middle-class blacks have succeeded beyond the wildest dreams of their grandparents; whites hire them with an eagerness beyond the wildest nightmares of some of their grandparents. And yet the survey data show resentment, fear for the future, anger.

Are the surveys right? Which aspect of the surveys should hold our attention-the absolute numbers or the changes over time? Is my interpretation of the complex pattern of beliefs tenable? Can political actors respond? To which set of beliefs should they respond? Can their responses make any differences? These rhetorical questions need real answers, both in order to address continuing problems of race in America and to probe further the relationship of public opinion to political action.

\section{Notes}

1. Results are from my reanalyses of the data collected by Angus Campbell and Howard Schuman in "Racial Attitudes in Fifteen American Cities," and from unpublished tabulations of Louis Harris and Associates in "The Unfinished Agenda on Race in America." The sample size in the first study was 3,230 black residents of cities; the second survey included a random national sample of 197 African Americans.

2. Results are from my reanalyses of data from The Gallup Poll, August 27-30, 1971, and "The American Dream," conducted by the Roper Organization for the Wall Street Journal, 1986. The first survey sampled 275 blacks; the second included 106.

\section{References}

Campbell, Angus, and Howard Schuman. 1968. "Racial Attitudes in Fifteen American Cities" (ICPSR Data Set \#3500, University of Michigan).

Gallup Organization. August 27-30, 1971. The Gallup Poll.

Hamilton, Charles. 1993. "Civil Rights Organizations and the Dual Agenda." Address at Princeton University, April 13.

Hochschild, Jennifer L. N.d. Race, Class, and the American Dream. Forthcoming.

Louis Harris and Associates. 1988. "The Unfinished Agenda on Race in America."

The Roper Organization. 1986. "The American Dream."

Wilson, William J. 1980. The Declining Significance of Race. Chicago: University of Chicago Press.

\footnotetext{
About the Author

Jennifer L. Hochschild is a professor of politics and public affairs at Princeton University. Among her publications are: The New American Dilemma (1984); "Disjunction and Ambivalence in Citizens' Political Outlooks," in Reconsidering the Democratic Public, ed. George Marcus and Russell Hanson (1992); and "Middle Class Blacks and the Complexities of Success," in Prejudice, Politics, and the American Dilemma, ed. Paul Sniderman and Philip Tetlock (1992).
} 